\title{
MENINGKATKAN AKTIVITAS DAN HASIL BELAJAR BIOLOGI MELALUI KEGIATAN PRAKTIKUM DI LABORATORIUM SISWA KELAS XI SEMESTER GENAP SMAN 1 RAMAN UTARAT.P. 2011/2012
}

\author{
Riska Desiana \\ Pendidikan Biologi FKIP Universitas Muhammadiyah Metro \\ E-mail:njeng_riska@yahoo.co.id
}

\begin{abstract}
Students are difficult to capture and master the assigned material, this is because students rarely engage actively in learning. Students in learning activities less than optimal due to the use of learning resources are generally limited to teachers and textbooks, not involving real-life learning resources that affect student learning outcomes. As an alternative to solving the problem, use the method in the laboratory practical activities. The advantages of this method is that students have the opportunity to test and implement in a real situation, which is derived from learning theory. This study aims to improve biological activity and learning outcomes. Based on the results of research can be summed up in a lab practicum activities can enhance biological activity and student learning outcomes. Advice of researchers to implement this method in the teaching of biology.
\end{abstract}

Kata kunci: Praktikum di Laboratorium, Aktivitas Belajar, Hasil Belajar Biologi.

Belajar biologi mencakup dua aspek kegiatan, yaitu belajar tentang biologi dan belajar melalui biologi. Belajar tentang biologi adalah belajar tentang bagaimana pengetahuan biologi diperoleh. Aspek kegiatan ini melibatkan tentang konsep biologi dan metodenya yang dikombinasikan dengan kegiatan inkuiri ilmiah. Sementara belajar mengenai biologi adalah bagaimana menggunakan pengetahuan biologi sebagai produk beserta metodenya untuk memulai dan memecahkan masalah-masalah baru. Kedua aspek ini sangat erat kaitanya dengan keterkaitan antara ilmu pengetahuan, teknologi dan masyarakat.

Kenyaatan di lapangan menunjukkan bahwa pendekatan pembelajaran yang digunakan bersifat konvensional. Guru lebih sering menggunakan metode ceramah bervariasi seperti tanya jawab, diskusi, atau dengan menggunakan media power point. Penekanan aktivitas belajar lebih banyak pada buku teks dan kemampuan mengungkapkan kembali isi buku teks tersebut, kurang menekankan pada keterlibatan siswa secara langsung dalam pembelajaran. Ketuntasan belajar siswa hanya diarahkan pada penguasaan konsep (kognitif), sehingga sangat sedikit menyentuh penumbuhan sikap ilmiah. Sikap ilmiah merupakan kecendrungan individu untuk bertindak atau berprilaku dalam memecahkan suatu masalah secara sistematis melalui langkah-langkah ilmiah. Sikap tersebut diantaranya sikap ingin tahu, sikap kritis, sikap obyektif, sikap ingin menemukan, sikap menghargai karya orang lain, sikap tekun, dan sikap terbuka. 
Tabel 1. Data Hasil Belajar Siswa Pra_PTK pada Materi Struktur dan Fungsi Sel.

\begin{tabular}{|l|l|l|l|l|}
\hline No & Nilai & Kategori & Jumlah & Persentase \\
\hline 1 & $<77$ & Tidak Tuntas & 16 & $51,6 \%$ \\
\hline 2 & $\geq 77$ & Tuntas & 15 & $48,4 \%$ \\
\hline Jumlah & $\mathbf{3 1}$ & $\mathbf{1 0 0 \%}$ \\
\hline
\end{tabular}

Sumber : Buku Daftar Nilai Biologi Semester Ganjil Kelas XI IPA $A_{1}$ SMA N 1 Raman Utara Tahun Pelajaran 2011/2012.

Dari hasil wawancara dengan guru bidang studi diketahui bahwa saat pelaksanaan proses pembelajaran biologi yang berlangsung selama ini menunjukkan sebagian besar siswa tampak kurang berminat, kurang bergairah dan cenderung tidak aktif. Hal ini ditunjukkan oleh sikap yang kurang antusias ketika pelajaran akan berlangsung, rendahnya respon umpan balik dari siswa terhadap pertanyaan dan penjelasan guru serta pemusatan perhatian yang kurang. Siswa jarang diajak untuk melakukan kegiatan praktikum oleh guru dengan alasan pengalaman belajar sudah dapat dihadirkan ke dalam kelas melalui media tanpa harus praktik langsung. Selain itu, guru juga masih mengalami kesulitan mengatur dan mengawasi siswa dalam melakukan kegiatan praktikum.

Dari tabel di atas, dapat diketahui bahwa masih banyak siswa yang nilainya belum mencapai standar KKM yaitu 77. Hal ini dapat dilihat dari jumlah siswa yang belum tuntas sebanyak $51,6 \%$ atau 16 dari 31 siswa. Ini berarti, lebih dari $50 \%$ siswa termasuk kategori belum tuntas atau belum mencapai standar yang diharapkan. Dengan demikian, hasil belajar siswa perlu untuk ditingkatkan.

Bloom, dkk (dalam Suprayekti, 2004:2-3) menyatakan belajar secara umum dapat diartikan sebagai proses perubahan prilaku akibat interaksi individu dengan lingkungan yang tidak terjadi dengan sendirinya karena proses kematangan, tetapi ada yang sengaja direncanakan. Sedangkan, mengajar merupakan seluruh kegiatan dan tindakan yang diupayakan oleh guru untuk terjadinya proses belajar sesuai dengan tujuan yang telah dirumuskan. Daryanto (2009:2) mendefinisikan belajar ialah suatu proses usaha yang dilakukan seseorang untuk memperoleh suatu perubahan tingkah laku yang baru secara keseluruhan, sebagai hasil pengalamannya sendiri dalam interaksi dengan lingkungannya. Sebagaimana yang diungkapkan Krisna (2009) bahwa pembelajaran adalah proses interaksi peserta didik dengan pendidik dan sumber belajar pada suatu lingkungan belajar. Pembelajaran merupakan bantuan yang diberikan pendidik agar dapat terjadi proses pemerolehan ilmu dan pengetahuan, penguasaan kemahiran dan tabiat, serta pembentukan sikap dan kepercayaan pada peserta didik. Dengan kata lain, pembelajaran adalah proses untuk membantu peserta didik agar dapat belajar dengan baik.

Pada dasarnya aktivitas belajar merupakan hal yang sangat mendasar, karena proses pembelajaran tidak akan berjalan dengan baik apabila tidak adanya aktivitas siswa dalam proses pembelajaran tersebut. Maka dalam proses pembelajaran diharapkan siswa dapat aktif, karena dengan keaktifan siswa tersebut dapat mencipta dengan baik. Sardiman (2010:95-96) mengungkapkan didalam belajar diperlukan aktivitas sebab pada prinsipnya belajar adalah berbuat untuk mengubah tingkah laku, jadi melakukan kegiatan. Tidak ada belajar kalau tidak ada aktivitas. Itulah 
sebabnya aktivitas merupakan prinsip/asas yang paling penting di dalam interaksi pembelajaran. Sukarman (2004:20) pada hakikatnya, belajar adalah wujud keaktifan siswa walaupun derajadnya tidak sama antara siswa satu dengan yang lainnya dalam suatu proses pembelajaran di kelas. Kata "aktif" sendiri dapat bermacammacam bentuk seperti: mendengarkan, menulis, membuat sesuatu, mendiskusikan. Tetapi terdapat banyak keaktifan yang tak dapat dilihat atau diamati, misalnya menggunakan hasanah ilmu pengetahuanya untuk memecahkan masalah. Agar siswa dapat berhasil baik dalam belajar maka dia harus terlibat aktif dalam aspek mental dan fisiknya. Aktivitas belajar yang dilakukan melalui kegiatan praktikum menurut Amin (dalam Rahayu, 2010:10) antara lain: mengamati, menggolongkan, mempersiapkan alat, mengukur, menjelaskan, mengajukan pertanyaanpertanyaan penting tentang alam, merumuskan, merumuskan hipotesis, merancang percobaan, menganalisis data, menarik kesimpulan dan sebagainya.

Agar terjadi proses interaksi belajar sesuai dengan yang diharapkan, maka guru harus terampil dalam memilih metode pembelajaran yang tepat dan menimbulkan keterlibatan siswa dalam pembelajaran. Kondisi pembelajaran yang baik sudah tentu mempengaruhi hasil belajar. Belajar dapat berhasil bila memiliki tujuan yang jelas dan kegiatan belajar telah diatur sehingga tujuan belajar mudah dicapai. Hamalik (dalam Fitriani, 2009:9) menyatakan hasil belajar bukan suatu penguasaan hasil latihan melainkan perubahan kelakuan. Hasil belajar merupakan nilai yang diperoleh siswa setelah adanya proses pembelajaran tertentu berupa aspek kognitif, psikomotorik, dan efektif. Djamarah dan Zein (dalam Daddy, 2008) menyebutkan hasil belajar adalah hasil yang di peroleh berupa kesankesan yang mengakibatkan perubahan dalam diri individu sebagai hasil dari aktivitas belajar setelah siswa menyelesaikan suatu paket belajar tertentu, yang dapat diukur dalam berbagai bentuk melalui proses evaluasi yang dicapai dapat berupa ranah kognitif (pengetahuan), afektif (sikap), dan psikomotorik (keterampilan) yang semuanya itu tercermin dalam hasil belajar siswa.

Praktikum merupakan salah satu dari faktor-faktor yang mempengaruhi hasil belajar siswa yang sangat berperan penting dalam menunjang keberhasilan proses pembelajaran IPA. Daryanto (2009:410) menyatakan metode pengajaran dengan kegiatan praktik adalah suatu sistem pembelajaran berupa perolehan kesempatan oleh semua peserta didik untuk melaksanakan suatu pekerjaan praktik, sehingga siswa akan memiliki pengetahuan dan keterampilan praktik serta akan bersikap sesuai dengan keterampilan tersebut (bersikap ilmiah). Metode praktikum menurut Yamin (2008:86) dapat dilakukan kepada siswa setelah guru memberikan arahan, aba-aba, petunjuk untuk melaksanakannya. Kegiatan ini berbentuk praktik dengan menggunakan alat-alat tertentu, dalam hal ini guru melatih keterampilan siswa dalam penggunaan alat-alat yang telah diberikan kepadanya serta hasil yang dicapai.

Kegiatan praktikum memiliki kelebihan dan kekurangan yang diungkapkan oleh Percival dan Ellington (dalam Daddy, 2008) antara lain: 1) Penyampaian bahan, menggunakan kegiatan dan pengalaman langsung dan konkrit. 
Kegiatan dan pengalaman demikian lebih menarik perhatian siswa dan memungkinkan pembentukan konsepkonsep abstrak yang mempunyai makna. 2) Lebih realistis dan mempunyai makna, sebab siswa bekerja langsung dengan contohcontoh nyata. Siswa langsung mengaplikasikan kemampuannya. 3) Para siswa belajar langsung menerapkan prinsip-prinsip dan langkah-langkah pemecahan masalah. 4) Banyak memberikan kesempatan bagi keterlibatan siswa dalam situasi belajar. Kegiatan demikian akan banyak membangkitkan motivasi belajar sebab kegiatan belajar akan disesuaikan dengan minat dan kebutuhan siswa. Sementara, beberapa kelemahan praktikum yang diungkapkan yaitu: 1) Membutuhkan waktu yang lebih lama dibandingkan dengan belajar secara teori. 2) Bagi siswa yang berusia muda, kemampuan berpikir rasional mereka masih terbatas. 3) Menuntut kemandirian, kepercayaan diri sendiri, kebiasaan bertindak sebagai subjek pada lingkungan yang kurang memberikan peran kepada anak sebagai subjek. Mereka lebih banyak diperlakukan sebagai objek. 4) Kesukaran dalam menggunakan faktor subjektifitasnya, terlalu cepat sampai kepada kesimpulan dan membuat generalisasi yang terlalu umum dari pengalaman yang sangat terbatas.

Margono

mengungkapkan

(2000:6) laboratorium merupakan suatu tempat atau ruangan yang dilengkapi dengan peralatan tertentu untuk melakukan percobaan atau penyelidikan. Laboratorium berperan sebagai tempat memberikan suatu ilustrasi materi teoritik. Disamping itu, laboratorium juga merupakan tempat siswa untuk mendapatkan kesempatan melakukan pengalaman langsung dalam memecahkan masalah yang diangkat dari fenomena yang diamati atau teori yang mereka pelajari. Berdasarkan hal tersebut di atas, peneliti bermaksud mengadakan penelitian tentang kegiatan praktikum di laboratorium untuk meningkatkan aktivitas dan hasil belajar siswa.

Berdasarkan latar belakang masalah, maka yang menjadi rumusan masalah dalam penelitian ini adalah: Apakah kegiatan praktikum di laboratorium dapat meningkatkan aktivitas dan hasil belajar biologi siswa kelas XI IPA 1 semester genap SMA N 1 Raman Utara?. Penelitian ini bertujuan untuk meningkatkan aktivitas dan hasil belajar biologi melalui kegiatan praktikum di laboratorium siswa kelas XI IPA 1 semester genap SMA N 1 Raman Utara. Sedangkan manfaat yang diharapkan dari penelitian ini yaitu: 1) Sebagai sumbangan pemikiran bagi guru IPA khususnya guru biologi tentang kegunaan kegiatan praktikum di laboratorium untuk meningkatkan hasil belajar biologi. 2) Memberi informasi kepada guru tentang pentingnya kegiatan praktikum di laboratorium dalam menunjang proses pembelajaran. 3) Memberi pemahaman pada siswa mengenai keterkaitan kegiatan praktikum di laboratorium dengan materi pelajaran.

\section{METODE}

Bentuk penelitian ini yaitu Penelitian Tindakan Kelas (PTK). Faktor yang diteliti adalah aktivitas dan hasil belajar biologi melalui kegiatan praktikum di laboratorium siswa pada kelas XI IPA 1 semester genap dengan materi pokok Makanan dan Sistem Pencernaan Makanan pada Manusia . Penelitian ini terdiri dari 2 siklus yang meliputi tahap-tahap dalam penelitian 
yaitu : 1) perencanaan, 2) pelaksanaan tindakan, 3) observasi dan evaluasi tindakan, dan 4) refleksi dari perjalanan setiap pertemuan yang dilaksanakan selama pembelajaran. Setiap siklus pembelajaran dilaksanakan selama 3 kali pertemuan yang terdiri dari 2 pertemuan observasi dan 1 pertemuan evaluasi dengan alokasi waktu setiap pertemuan (2x45 menit). Penelitian dilaksanakan mulai tanggal 02 Februari sampai dengan 18 Februari 2012, dilaksanakan di SMA N 1 Raman Utara pada semester genap tahun pelajaran 2011/2012 yang menjadi subjek penelitian adalah siswa kelas XI IPA 1 sebanyak 31 siswa.

Dalam penelitian ini, peneliti melakukan tahap-tahap penelitian dengan terlebih dahulu mengkaji materi yang akan dilakukan dalam proses pembelajaran selama penelitian, setelah itu mempersiapkan segala perangkat pembelajaran yang akan digunakan selama penelitian seperti silabus, rencana pelaksanaan pembelajaran (RPP), menyusun panduan kegiatan praktikum, menyiapkan lembar observasi siswa dan guru, pembentukan kelompok praktikum, serta soal evaluasi.

Pada tahap pelaksanaan, peneliti melaksanaan pembelajaran dengan penerapan metode pembelajaran melalui kegiatan praktikum di laboratorium serta mengamati aktivitas yang dilakukan siswa selama praktikum berlangsung melalui kegiatan observasi oleh 3 orang observer dengan cara memberi tanda check list () pada kolom yang telah tersedia dalam lembar observasi siswa. Pada setiap akhir siklus diadakan tes evaluasi dengan memberi 20 soal pilihan ganda dengan maksimal waktu 20 menit yang digunakan sebagai tolak ukur kemampuan siswa dalam memahami materi yang diberikan oleh peneliti. Pada tahap akhir adalah refleksi dilakukan pada setiap akhir siklus dalam mengkaji pembelajaran yang dilakukan.

\section{HASIL}

Berdasarkan hasil penelitian baik pada siklus I dan II diketahui bahwa penggunaan pembelajaran dengan metode kegiatan praktikum di laboratorium dapat meningkatkan aktivitas dan hasil belajar siswa menjadi lebih baik dari sebelumnya. Sehingga data peningkatan hasil belajar siswa Pra-PTK, Siklus I dan Siklus II dapat dilihat pada Gambar 1.

Berdasarkan hasil penelitian yang telah diuraikan, diperoleh data bahwa pembelajaran dengan metode kegiatan praktikum di laboratorium dapat meningkatkan aktivitas belajar siswa. Adapun peningkatan aktivitas belajar siswa dapat dilihat pada Tabel 3. Data peningkatan aktivitas belajar siswa Siklus I dan Siklus II berdasarkan tabel 2 tersebut dapat digambarkan pada Gambar 2.

Tabel 2. Data Peningkatan Hasil Belajar Siswa Pra-PTK, Siklus I dan Siklus II.

\begin{tabular}{|l|l|l|l|l|}
\hline \multirow{2}{*}{ No } & \multirow{2}{*}{ Nilai Kategori } & \multicolumn{4}{|l|}{ Ketuntasan Belajar } \\
\cline { 3 - 5 } & $<$ & Pra-PTK & Siklus I & Sklus II \\
\hline $\mathbf{1 .}$ & $<77$ & $16(51,6 \%)$ & $13(41,9 \%)$ & $5(16,2 \%)$ \\
\hline $\mathbf{2 .}$ & $\geq 77$ & $15(48,4 \%)$ & $18(58,1 \%)$ & $26(83,8 \%)$ \\
\hline
\end{tabular}




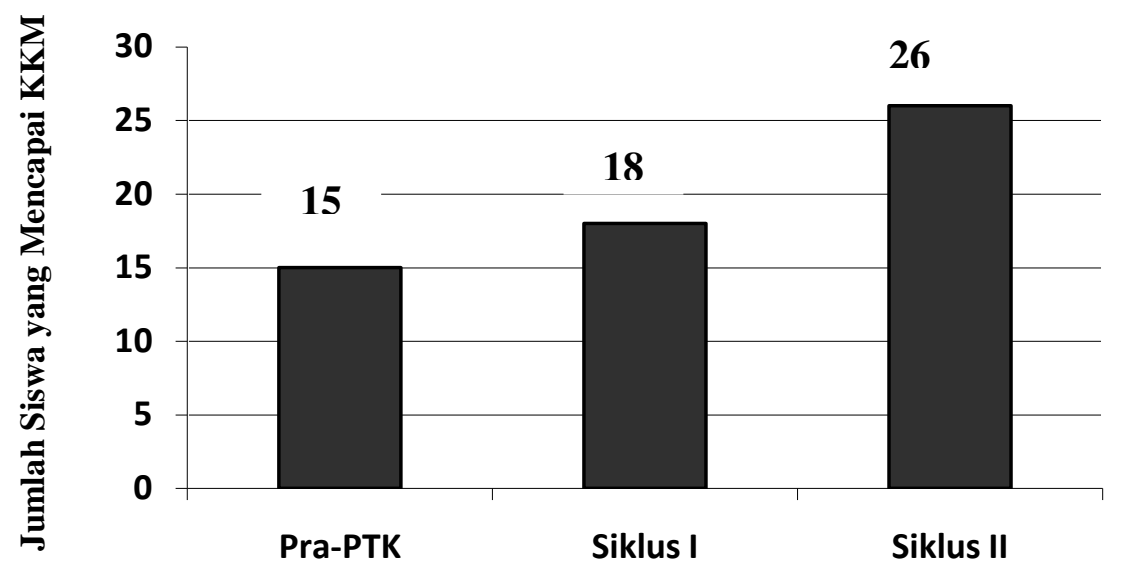

Gambar 1. Peningkatan Hasil Belajar Siswa Pra-PTK, Siklus I Dan Siklus II.

Tabel 3. Data Peningkatan Aktivitas Belajar Siswa Siklus I dan Siklus II.

\begin{tabular}{|l|l|l|l|l|l|l|}
\hline No & Indikator Aktivitas & $\begin{array}{l}\text { Siklus } \\
\text { I }\end{array}$ & $\begin{array}{l}\text { Siklus } \\
\text { II }\end{array}$ & $\begin{array}{l}\text { Pening- } \\
\text { katan }\end{array}$ & $\begin{array}{l}\text { Keterca- } \\
\text { paian } * \text { ) }\end{array}$ & $\begin{array}{l}\text { Indikator } \\
\text { Keberhasilan }\end{array}$ \\
\hline 1. & $\begin{array}{l}\text { Bekerjasama di dalam } \\
\text { kelompok }\end{array}$ & $58 \%$ & $83,8 \%$ & $25,8 \%$ & + & $75 \%$ \\
\hline 2. & $\begin{array}{l}\text { Melakukan kegiatan } \\
\text { praktikum }\end{array}$ & $56,4 \%$ & $100 \%$ & $43,6 \%$ & + & $95 \%$ \\
\hline 3. & Menggunakan alat & $75,8 \%$ & $100 \%$ & $24,2 \%$ & + & $75 \%$ \\
\hline 4. & $\begin{array}{l}\text { Mengkomunikasikan hasil } \\
\text { kegiatan praktikum }\end{array}$ & $59,6 \%$ & $100 \%$ & $40,4 \%$ & + & $85 \%$ \\
\hline 5. & Memberi kesimpulan & $62,8 \%$ & $85,4 \%$ & $22,6 \%$ & + & $75 \%$ \\
\hline
\end{tabular}

Keterangan: $+=$ Tercapai

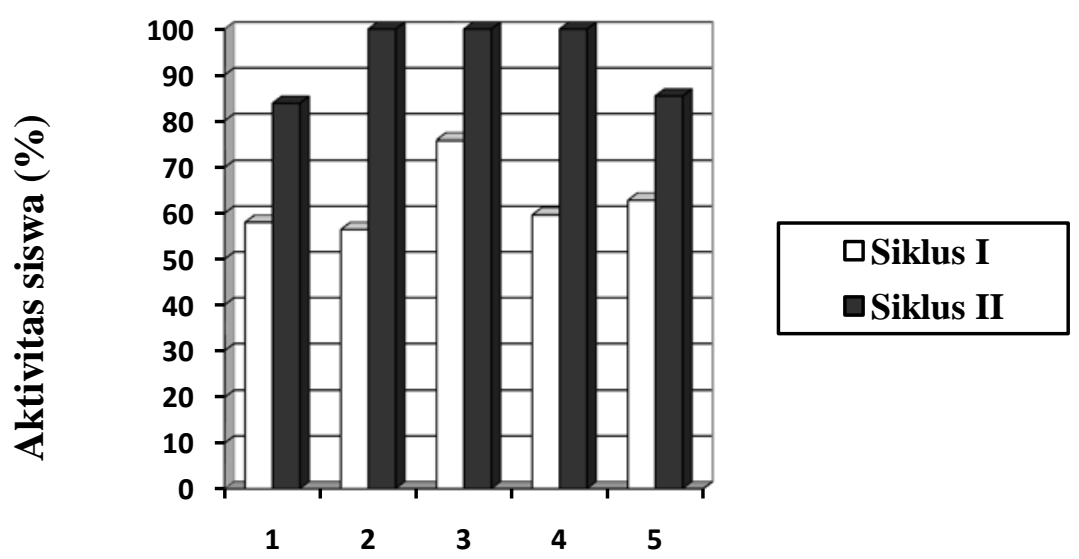

Indikator Aktivitas yang Diamati

Gambar 2. Peningkatan Aktivitas Belajar Siswa Siklus I dan Siklus II 


\section{PEMBAHASAN}

Berdasarkan tabel dan grafik hasil penelitian tersebut dapat diketahui bahwa:

\section{A. Hasil Belajar}

Sedangkan untuk hasil belajar siswa rata-rata pada siklus I mencapai 76,7 dan pada siklus II meningkat menjadi 80,6. Hal ini disebabkan karena kelemahan pada siklus I yaitu siswa merasa kurang nyaman dengan kelompok, dan aktivitas negatif yang dilakukan siswa telah berhasil diatasi pada pelaksanaan siklus II. Hasil pada siklus II telah mencapai indikator keberhasilan tindakan yaitu siswa yang mendapat nilai $\geq 77$ sebanyak 83,8\% atau 26 siswa dari jumlah seluruh siswa yaitu 31 siswa.

\section{B. Aktivitas Belajar \\ 1. Bekerjasama Kelompok}

Siklus 1, aktivitas belajar siswa saat pembelajaran yang aktif bekerjasama dengan kelompoknya sebanyak 58\% sedangkan $42 \%$ siswa belum terbiasa dengan anggota kelompok, menyebabkan kurang terjalin kerja sama yang baik antar anggota kelompok misalnya ditunjukkan dengan adanya pembagian tugas antar anggota kelompok tersebut. Setiap anggota kelompok memiliki tugas masing-masing diantaranya ada yang bertugas melakukan kegiatan praktikum, mencatat hasil kegiatan yang dilakukan teman-tamannya, dan berperan dalam mengkaji literatur sehingga tidak ada anggota kelompok yang berdiam diri.

Seperti yang diungkap Subiyanto (1998:80) yang menyebutkan salah satu kegunaan laboratorium IPA dapat memberi peluang bagi para siswa untuk bekerjasama dengan teman-teman sehingga memiliki gairah yang kuat untuk mengungkapkan atau menemukan sesuatu yang tidak dapat diketahui dan dapat menikmati kepuasan atau hasil yang dapat dicapai. Pada siklus II adaptasi siswa sudah mulai terlihat hal ini ditunjukkan dengan aktivitas siswa mengalami peningkatan sebesar 25,8\%. Peningkatan itu terjadi karena siswa telah terbiasa beradaptasi dengan anggota kelompok mereka masingmasing.

\section{Melakukan Kegiatan Praktikum \\ Daryanto (2009:410) menyatakan} metode pengajaran dengan kegiatan praktik adalah suatu sistem pembelajaran berupa perolehan kesempatan oleh semua peserta didik untuk melaksanakan suatu pekerjaan praktik, sehingga siswa akan memiliki pengetahuan dan keterampilan praktik serta akan bersikap sesuai dengan keterampilan tersebut (bersikap ilmiah). Siklus I sebanyak 43,6\% siswa belum melakukan kegiatan praktikum dengan benar dan runtun, sesuai dengan petunjuk praktikum. Bahkan ada siswa yang ngobrol dengan teman, berdiam diri dan hanya mengamati teman yang melakukan kegiatan praktikum, maupun asyik dengan kegiatan sendiri. Kegiatan praktikum yang diharapkan adalah siswa melakukan percobaan secara runtun, sesuai petunjuk praktikum yang tersedia. Namun pada siklus II siswa yang melakukan kegiatan praktikum mengalami peningkatan sebesar 43,6\%. Peningkatan terjadi karena guru selalu memberikan bimbingan, khususnya siswa yang tidak melakukan kegiatan praktikum, mengenai pentingnya kegiatan praktikum dalam menunjang proses pembelajaran sehingga siswa termotivasi untuk melakukan kegiatan praktikum sesuai dengan petunjuk yang tersedia. 


\section{Menggunakan Alat}

Siswa yang melakukan aktivitas menggunakan alat dengan benar sesuai prosedur pada siklus I hanya sebesar $75 \%$ sedangkan $25 \%$ siswa belum sesuai terutama dalam menggunakan pipet tetes sehingga larutan banyak yang mengotori dinding tabung kemudian guru menjelaskan kembali dengan lebih rinci melalui petunjuk praktikum mengenai prosedur dalam melakukan kegiatan praktikum, cara menggunakan alat dan bahan yang benar. Aktivitas siswa dalam menggunakan alat yang diharapkan atau sesuai indikator adalah siswa menggunakan alat sesuai dengan prosedur yang tersedia dalam petunjuk praktikum sehingga kegiatan praktikum dapat berjalan lancar dan siswa terhindar dari hal-hal yang tidak diinginkan akibat keteledoran dalam melakukan kegiatan praktikum.

Pada siklus II semua siswa telah mampu menggunakan alat dengan benar sesuai prosedur. Peningkatan itu terjadi karena guru menjelaskan kembali kepada siswa mengenai penggunaan alat-alat praktikum dengan lebih terperinci. Daddy (2008) "Proses pembelajaran dalam ruang lingkup mata pelajaran ilmu pengetahuan alam lebih menitikberatkan pada kemampuan siswa secara ilmiah, yang dalam pelaksanaannya memerlukan kemampuan secara khusus atau dengan kata lain hasil yang diperoleh setelah mata pelajaran tidak hanya berupa informasi pengetahuan saja namun keterampilan penggunaan alat laboratorium pun bisa diperoleh siswa tersebut”. Subiyanto (1998:81) mengungkapkan salah satu tujuan pelajaran yang menggunakan laboratorium yaitu mengembangkan keterampilan siswa melalui pengamatan, pencatatan data, penggunaan alat dan membuat alat-alat sederhana.

\section{Mengkomunikasikan Hasil}

Siswa mengkomunikasikan hasil kegiatan praktikum dalam bentuk tabel, gambar atau menjawab pertanyaan sesuai perintah yang tersedia dalam LKS. Pada siklus 1, siswa yang melaporkan hasil kegiatan mereka hanya sebesar $59,6 \%$ sedangkan siswa lainnya tidak terlibat diskusi untuk melaporkan hasil kegiatan praktikum. Siswa yang melakukan praktikum kemudian berdiskusi dengan anggota kelompoknya untuk melaporkan hasil kegiatan praktikum mereka dengan menjawab pertanyaan yang tersedia pada LKS. Sehingga mempengaruhi kemampuan siswa dalam menyimpulkan hasil kegiatan praktikum yang baru saja berlangsung. Kemudian guru memberikan bimbingan tentang pentingnya melakukan kegiatan praktikum sehingga siswa termotivasi untuk melakukan kegiatan praktikum. Hal ini dapat dilihat pada siklus II semua siswa telah melaporkan hasil kegiatan mereka. Aktivitas siswa dalam mengkomunikasikan hasil kegiatan seperti diungkapkan Subiyanto (1998:81) salah satu tujuan pelajaran yang menggunakan laboratorium yaitu melatih ketelitian, kejelasan serta melaporkan hasil percobaan siswa, dalam penelitian ini berupa tabel dan gambar.

\section{Memberi Kesimpulan}

Pada siklus I siswa yang melakukan aktivitas memberi kesimpulan adalah sebesar 62,8\% sedangkan sebanyak 37,2\% siswa yang tidak melakukan kegiatan praktikum sehingga tidak mampu memberikan kesimpulan dari kegiatan praktikum yang baru saja berlangsung. Seiring dengan semakin meningkatnya 
keaktifan siswa dalam melakukan kegiatan praktikum serta bimbingan guru terhadap siswa dalam mengkomunikasikan hasil kegiatan dan menarik kesimpulan sehingga aktivitas kegiatan siswa pada siklus II meningkat menjadi 85,4\%. Menurut Amin (dalam Rahayu, 2010:10) aktivitas belajar melalui praktikum antara lain:mengamati, mempersiapkan alat, mengajukan pertanyaanpertanyaan penting tentang alam, merumuskan, menganalisis data, dan menarik kesimpulan. Aktivitas siswa tersebut sebagaimana diungkapkan Arsyad (dalam Daddy, 2008) "Belajar yang paling baik adalah melalui pengalaman langsung”. Dalam belajar melalui pengalaman langsung siswa tidak sekedar mengamati secara langsung tetapi ia harus menghayati, terlibat langsung dalam perbuatan dan bertanggung jawab terhadap hasilnya.

\section{KESIMPULAN DAN SARAN Kesimpulan}

Berdasarkan hasil analisis data dan pembahasan dapat diambil kesimpulan bahwa Kegiatan praktikum di laboratorium dapat meningkatkan aktivitas dan hasil belajar biologi siswa kelas XI IPA 1 semester genap SMA N 1 Raman Utara tahun pelajaran 2011/2012.

\section{Saran}

Berdasarkan hasil observasi, pembelajaran dengan menggunakan metode kegiatan praktikum di laboratorium pada siswa kelas XI IPA SMA Negeri 1 Raman Utara, maka penulis memberikan saran sebagai berikut: 1) Metode pembelajaran kegiatan praktikum di laboratorium hendaknya dijadikan salah satu alternatif dalam pembelajaran biologi bagi guru untuk menumbuhkan minat serta motivasi dan keterlibatan siswa dalam mempelajari biologi dan agar guru lebih memanfaatkan sarana dan prasarana yang tersedia di sekolah. 2) Dalam melakukan kegiatan praktikum di laboratorium, siswa harus dibekali dengan pemahaman tentang penggunaan alat dan bahan maupun langkah-langkah kegiatan praktikum agar kegiatan praktikum dapat berjalan dengan lancar dan efektif serta siswa terhindar dari hal-hal yang tidak diinginkan yang diakibatkan oleh kesalahan dalam kegiatan praktikum. 3) Bekerjasama antar anggota kelompok sangat diperlukan, untuk itu guru harus mampu mengkondisikan siswa sehingga terjalin kerja sama yang baik di dalam kelompok tersebut.

\section{DAFTAR RUJUKAN}

Daddy, Pascal. 2008. Penerapan Metode Praktikum dalam Meningkatkan Hasil Belajar Kimia Siswa dalam Pokok Bahasan Asam dan Basa di SMP. (Online).

(http://pascaldaddy512.wordpres s.com diakses 21 November 2011 Pukul 10:30 WIB).

Daryanto. 2009. Panduan Proses Pembelajaran Kreatif dan inovatif. Jakarta: Publisher.

Fitriani, Nita. M. 2009. Peningkatan Aktivitas dan Hasil Belajar Fisika Melalui Kegiatan Praktikum di Laboratorium pada Siswa Kelas $X \quad$ SMA Muhammadiyah 1 Kalirejo. Skripsi. Tidak diterbitkan. Metro:Program SI Universitas Muhammdiyah Metro. 
Harjanto. 2006 . Perencanan Pengajaran. Jakarta: Rineka Cipta.

Krisna. 2009. Pengertian dan Ciri-ciri Pembelajaran. ( Online) (http://krisna1.blog.uns.ac.id. diakses 19 Oktober 2011 Pukul 11:00 WIB).

Margono, Hadi. 2000. Metode

Laboratorium. Malang:

Universitas Negeri Malang.

Rahayu, Tri. 2010. Penerapan Eksperimen dalam Meningkatkan Aktivitas dan Hasil Belajar Fisika Siswa SMP N 1 Seputih Raman. Skripsi. Tidak diterbitkan. Metro: Program SI Universitas Muhammadiyah Metro.

Sardiman. 2010. Interaksi dan Motivasi Belajar Mengajar. Jakarta: Rajawali Pers.

Subiyanto. 1998. Pendidikan Ilmu Pengetahuan Alam. Jakarta: Direktorat Jendral Tinggi Proyek Bimbingan Lembaga Tenaga Pendidikan.

Sukarman, Hery. 2004. Dasar-dasar Pembelajaran. Jakarta: Direktorat Jendral Pendidikan Dasar dan Menegah. Departemen Pendidikan Nasional.

Suprayekti, Dkk. 2004. Interaksi Belajar Mengajar. Jakarta: Direktorat Jendral Pendidikan Dasar dan Menegah. Departemen Pendidikan Nasional.
Yamin, Martinis. 2008. Paradigma Pendidikan Konstruktivistik. Jakarta: Gaung Persada Press. 